\title{
Comparison of serum leptin, glucose, total cholesterol and total protein levels in fertile and repeat breeder cows
}

\begin{abstract}
Saime Guzel ${ }^{1}$, Meltem Tanriverdi ${ }^{1}$
${ }^{1}$ Department of Biochemistry, Faculty of Veterinary Medicine, University of Uludag, Görükle, Bursa, Turkey.

ABSTRACT - In the present study we measured serum glucose, leptin, total cholesterol and total protein concentrations in repeat breeder cows and compared them with fertile cows. For this aim, 20 repeat breeder cows and 20 fertile cows were used as material. Repeat breeder cows were found to have lower levels of leptin and glucose as compared with fertile ones. No significant differences in total cholesterol and total protein levels were observed between the two groups. No significant correlation of leptin with glucose, total cholesterol and total protein was observed in fertile and repeat breeder cows. Low concentrations of glucose and leptin can have some effects on reproductive problems as repeat breeder and help to understand potential mechanisms impairing fertility in repeat breeder cows.
\end{abstract}

Key Words: adipose tissue, cow, leptin hormone, reproductive problem

\section{Introduction}

The term "repeat breeder" or "repeat breeder syndrome" has been coined to describe cows that failed to conceive after three or more inseminations. Repeat breeding is an important factor involved in infertility, which has become a major source of economic losses in the cattle industry due to the need for more inseminations, reduced milk production, increased calving interval and increased culling rates (Parkinson, 2001). Fertility requires adequate nutrition and energy reserves. Starvation, wasting and obesity are associated with reproductive system abnormalities and infertility. It is evident that the energy balance plays a significant role in reproductive function and fertility. This effect of nutrition and/or energy reserves on reproductive function has long been suspected to be mediated by metabolic signal(s) that link adipose stores with neuroendocrine function (Goumenou et al., 2003; El-Khadrawy et al., 2011). In recent years, the substantial increase in the incidence of reproductive cycle abnormalities, falling pregnancy rates and the search for an endocrine link with fertility in modern dairy cows have promoted a focus on leptin (Opsomer et al., 1998; Royal et al., 2000). Leptin, a $16-\mathrm{kD}$ protein product of the obese gene $(\mathrm{ob})$ produced primarily by adipocytes of white

Received May 28, 2014 and accepted October 10, 2014

Corresponding author: saime@uludag.edu.tr

http://dx.doi.org/10.1590/S1516-35982014001200003

Copyright $@ 2014$ Sociedade Brasileira de Zootecnia. This is an Open Access article distributed under the terms of the Creative Commons Attribution Non-Commercial License, which permits unrestricted non-commercial use, distribution, and reproduction in any medium, provided the original work is properly cited. adipose tissue, plays an important role in the regulation of energy balance, food intake and body weight. In addition to white adipose tissue, the major source of leptin, it can also be produced by brown adipose tissue, ovaries, placenta (syncytiotrophoblasts), stomach (lower part of fundic glands), mammary epithelial cells, skeletal muscle, bone marrow, pituitary and liver. It is now generally accepted that leptin is produced mainly by adipose tissue and relays information to the brain concerning the amount of energy stores and activates areas of the brain that regulate energy uptake and expenditure (Considine et al., 1996; Nagatani et al., 2000). While numerous studies have investigated the biology of leptin in a wide range of species (Chilliard et al., 2001; Spicer, 2001), much remains to be learned about leptin levels in postpartum dairy cows and how leptin levels relate to reproductive function at this time in this commercially important species. Recent data suggest that this hormone may influence reproduction and provided the biochemical basis of the communication that exists between fat stores and the brain (Goumenou et al., 2003; El-Khadrawy et al., 2011). In previous studies negative energy balance in the postpartum period of lactating cows was also linked to reduced leptin levels and delayed resumption of cyclicity (Kadokawa et al., 2000; Block et al., 2001).

Normal blood levels of various biochemical components are essential for normal function of various systems in the body including reproductive system. Changes in several biochemical components have been blamed for reproductive failures. Thus, the serum biochemical profile might be helpful in characterizing these problems. Blood glucose, cholesterol and protein appear to be some of the 
key nutrients affecting fertility and cyclicity in farm animals (Qureshi, 1998; Park et al., 2010). Therefore, the present study was designed, firstly, to compare circulatory levels of leptin, glucose, total cholesterol and total protein in repeat breeder and fertile cows. Secondly we sought to determine the relationships of serum leptin levels to glucose, total cholesterol and protein levels, since leptin has important roles in glucose, lipid and protein metabolism (Haluzik et al., 1999; Henry et al., 1999).

\section{Material and Methods}

Repeat breeder and fertile cows (20 fertile and 20 repeat breeders) were selected on the basis of reproductive performance among a population of Holstein cows in dairy herds located on Karacabey Stud Farm, Bursa, Turkey. The experimental procedures were approved by the Animal Care Committee of University of Uludag, Bursa, Turkey. All animals were clinically free of disease, aged 3-6 years and had no history of calving difficulty in the previous parturition. Fertile cows in the same postpartum period became pregnant after one or two inseminations. Cows were identified as repeat breeder after being artificially inseminated up to ten times without becoming pregnant despite having normal oestrous cycles and oestrus period and clear vaginal mucus discharge at oestrus. There was no evidence of genital tract pathologies being diagnosed after rectal palpation and ultrasonic examination. All cows selected for the present study were in the second lactation period, most of them having an average milk yield ranging from 8,000 to $9,000 \mathrm{~L}$; body weight $615 \pm 24 \mathrm{~kg}$ and $585 \pm 18 \mathrm{~kg}$ in fertile and repeat breeder cows, respectively; and body condition score of 3-4 (a numerical range of 1-5 identifies varying degrees of fatness, with 1 being very thin and 5 being excessively fat).

These experimental cows were fed green grass/fodder ad libitum and had free access to water. The amount of concentrate feed given to the animals was calculated by the computer-controlled feeding system in which the food requirement of each animal was taken in to account. Forage was given to the animals on the farm as ad libitum in the morning and evening. As forage, corn straw, corn silage, brewer's grain (crude protein $=4.88 \%$, crude fat $=1.51 \%$, crude cellulose $=43.0 \%$ ) and as concentrate feed, a mixture containing wheat, barley, full fat soybean, cottonseed meal, sunflower meal, corn and scurf (crude protein $=15.38 \%$, crude fat $=2.57 \%$, crude cellulose $=7.17 \%$ ) were given to the animals.

Blood samples were collected from the jugular vein in to serum separator tubes (Venoject). After clotting at room temperature, sera were separated by centrifugation at $3,000 \times g$ for $10 \mathrm{~min}$ and transferred to plastic tubes. Sera were stored at $-80{ }^{\circ} \mathrm{C}$ until the time of analysis.

Serum leptin concentrations were measured using a double antibody radioimmunoassay (RIA) kit containing guinea pig multispecies leptin antibody, human [125I ] leptin, and as standard, human leptin (Linco, Multispecies Leptin RIA Kit, Cat\#XL-85K) following the manufacturer`s instructions. Serum glucose concentration was measured by the glucose/oxidase method using a commercial kit (Biolabo, Glucose GOD-PAP, Cat.No 87109). Serum total cholesterol and total protein levels were measured using a Technicon DAX 72 autoanalyzer and accompanying kits.

The data were analyzed using the statistical software program SPSS 10.0 for Windows. Data was expressed as mean and standard error. Mann-Whitney $U$ test from nonparametric tests was applied to evaluate any differences between groups and $\mathrm{P}<0.05$ was considered as statistically significant. Correlations between leptin, and total cholesterol and protein were assessed using Pearson's correlation coefficient.

\section{Results and Discussion}

We observed lower levels of leptin and glucose but no significant differences of total cholesterol and protein in repeat breeder cows as compared with fertile ones (Table 1). Adipose tissue secretes various bioactive molecules like leptin that may directly contribute to the development of obesity-related diseases. Most of the information on the reproductive role of leptin hormone was obtained from ob/ob mice (mice with a mutated leptin gene and resulting hormone insufficiency. Both male and female ob/ob mice were obese and infertile. Food limitations and loss of weight did not lead to reinstatement of fertility. On the contrary, fertility was reinstated with the administration of recombinant leptin (Barash et al., 1996; Mounzih et al., 1997). Sivan et al. (1998) demonstrated that serum leptin concentrations have been shown to increase in pregnant women and to correlate with serum levels of gestational

Table 1 - Serum leptin, total cholesterol and total protein levels of fertile and repeat breeder cows $(n=20)^{1}$

\begin{tabular}{lcc}
\hline Parameters & Fertile cows & Repeat breeder cows \\
\hline Serum leptin $(\mathrm{mg} / \mathrm{dL})$ & $5.12 \pm 0.43$ & $3.63 \pm 0.25^{*}$ \\
Serum glucose $(\mathrm{mg} / \mathrm{dL})$ & $65.00 \pm 6.27$ & $44.71 \pm 5.17^{*}$ \\
Serum total cholesterol $(\mathrm{mg} / \mathrm{dL})$ & $112.10 \pm 3.57$ & $126.10 \pm 9.74$ \\
Serum total protein $(\mathrm{mg} / \mathrm{dL})$ & $7.09 \pm 0.27$ & $7.92 \pm 0.31$ \\
\hline
\end{tabular}

${ }^{1}$ Means of all parameters in fertile and repeat breeder cows \pm standard error of the mean.

$* \mathrm{P}<0.05$. 
hormones. Cioffi et al. (1997) found that a postovulatory rise in serum leptin concentrations was associated with implantation potential in women undergoing infertility treatment. Mann et al. (2005) identified postpartum reproductive cycle abnormalities in around $40 \%$ of dairy cows and concluded that aberrant reproductive function was also associated with reduced plasma concentrations of leptin. In accordance with these studies, we also found lower concentrations of serum leptin in the repeat breeder cows than in the fertile cows $(\mathrm{P}<0.05)$ (Table 1$)$.

Repeat breeder cows were found to have lower levels of glucose compared with fertile ones $(\mathrm{P}<0.05)$ (Table 1). Dutta et al. (1988) reported significantly lower serum glucose level in an-oestrus than normally cycling animals. Ahmad et al. (2004) demonstrated that the serum glucose level of endometritic cows was significantly higher than in cyclic and non-cyclic animals (endometric, $58.08 \pm 2.59 \mathrm{~g} / \mathrm{dL}$; cyclic, $50.72 \pm 1.12 \mathrm{~g} / \mathrm{dL}$; non-cyclic, $50.56 \pm 1.13 \mathrm{~g} / \mathrm{dL}$ ). In another study, Majeed et al. (1990) recorded higher serum glucose level in endometritic animals than in healthy ones. In the present study, reduced blood glucose levels in repeat breeder cows may result from either instability between hepatic output and peripheral uptake of the glucose or defects in the endocrine regulatory mechanisms, which influence these processes. Abnormal functioning of hormone-producing organs may influence glucose levels.

There were no significant differences regarding total cholesterol levels between the fertile and repeat breeder cows (Table 1). This is in agreement with the reports of Ceylan et al. (2007), Ramakrishna (1996) and Singh and Pant (1998), who reported lower cholesterol levels in repeat breeders than in normally cycling cows, whereas Dutta et al. (1991) observed higher cholesterol levels in repeat breeders than in normally cycling cows. Guedon et al. (1999) reported that cholesterol levels in cows may vary depending on various physiological factors, such as pregnancy and lactation, and low cholesterol levels may affect the reproductive performance. Burle et al. (1995) reported lower serum cholesterol concentration in anestrous than in cycling cows. Salmanoglu et al. (1997) demonstrated that cows showing irregular cycles or subestrus were found to have lower levels of cholesterol compared with normal ones. In the same study it was also reported that cholesterol might have an effect on the cows showing irregular cycles or subestrus because it is a key ingredient for construction of progesterone. Ahmad et al. (2004) showed significantly higher serum cholesterol in endometritic as compared with cyclic and non-cyclic cows. Majeed et al. (1990) found nonsignificant differences in serum cholesterol levels between endometritic and healthy buffaloes.
No significant difference was observed in total protein levels between fertile and repeat breeder cows (Table 1). This finding is in agreement with reports of Gandotra et al. (1993) and Ramakrishna (1996). Low plasma protein levels resulted in the deficiency of certain amino acids required for the biosynthesis of gonadotropins and gonadal hormones and might cause reproductive hormonal disturbances in animals, leading to inactive ovaries (Vohra et al., 1995; Arosh et al., 1998). Ahmad et al. (2004) reported significantly higher total protein level in endometritic $(19.16 \pm 1.00 \mathrm{~g} / \mathrm{dL})$ cows as compared with cyclic and noncyclic cows. Furthermore, the total protein level in noncyclic cows $(15.23 \pm 0.89 \mathrm{~g} / \mathrm{dL})$ was significantly higher than that of cyclic animals $(9.19 \pm 0.45 \mathrm{~g} / \mathrm{dL})$. El-Azab et al. (1993) and Burle et al. (1995) reported significantly higher value of total serum protein in cyclic cows than in noncycling cows. Lyubestsky (1997) revealed higher values of total serum protein in endometritic buffaloes and cows as compared with cyclic buffaloes and cows, respectively.

Non-significant correlation was found between leptin and glucose levels in fertile and repeat breeder cows (Table 2). Different results were obtained in various studies evaluating the relationship between leptin and glucose concentrations. Subcutaneous administration of leptin was reported to decrease plasma glucose concentration in rats (Sivitz, 1997). On the other hand, Henry et al. (1999) observed no effect on glucose concentration in sheep administered intracerebroventricular (icv) leptin. Block et al. (2003) reported that leptin concentrations tend to correlate positively with plasma glucose levels in dairy cattle.

Cholesterol is a form of lipid, or fat, that circulates in the bloodstream. it is necessary for life itself. Cholesterol is essential for building and maintaining key parts of cells (such as cell membranes) and making several essential hormones (sex hormone, aldosterone, etc.). Cholesterol is increased with obesity, which makes the subject face double risk to develop cardiovascular disease, diabetes mellitus, and reproductive disorders (Ahmad et al., 2004). In the present study, there was no significant correlation between leptin and total cholesterol levels in repeat breeder and

Table 2 - Correlation of serum leptin and serum glucose, total cholesterol and total protein levels in fertile and repeat breeder cows

\begin{tabular}{lcc}
\hline \multirow{2}{*}{ Parameters } & \multicolumn{2}{c}{ Leptin } \\
\cline { 2 - 3 } & Fertile cows & Repeat breeder cows \\
\hline Serum glucose & 0.100 & -0.115 \\
Serum total cholesterol & -0.360 & -0.432 \\
Serum total protein & -0.080 & 0.140 \\
\hline
\end{tabular}

The numbers shown are the $r$ value. 
fertile cows (Table 2). Our findings were consistent with other studies conducted by Yadav et al. (2011). Haluzik et al. (1999) investigated the relationship between serum leptin concentrations and total cholesterol levels in patient combined with hyperlipidemia and healthy controls. No statistically significant relationship was found between serum leptin and total cholesterol concentration in either combined hyperlipidemia group or controls. In contrast, it was found that the leptin hormone increased with the increase in total cholesterol (Taleb et al., 2014). In 2007, a study conducted by Zabut et al. (2007) on adults of Gaza Strip also examined whether Leptin and soluble Leptin receptor (OB-Re) were statistically correlated with lipid parameters among all study subjects. It was found that serum leptin levels were positively correlated with total cholesterol.

Malnutrition is one of many factors which cause repeat breeder syndrome. Serum total protein level is a biochemical marker in protein-energy malnutrition (Haile et al., 2014). Serum leptin levels were not found to be correlated with malnutrition markers (total protein, etc.) (Yllmaz et al., 2005). Amirkalali et al. (2010) suggested that serum leptin can be a good predictor of energy malnutrition, but they could not find a significant correlation between leptin and total protein levels in elderly patients. In accordance with previous reports, we also did not find a significant correlation between leptin and total protein levels (Table 2).

\section{Conclusions}

Repeat breeder cows are found to have lower levels of leptin and glucose as compared with fertile ones. We believe that the low concentrations of leptin hormone and glucose can have some effects on reproductive problems such as repeat breeder syndrome, and these parameters may be helpful in characterizing these problems. On the other hand, our results can help to establish the physiological role of these parameters in the reproductive process and understand potential mechanisms impairing fertility in repeat breeder cows.

\section{References}

Ahmad, I.; Lodhi, L. A.; Qureshi, Z. I. and Younis, M. 2004. Studies on blood glucose, total proteins, urea and cholesterol levels in cyclic, non-cyclic and endometritic crossbred cows. Pakistan Veterinary Journal 24:92-94.

Amirkalali, B.; Sharifi, F.; Fakhrzadeh, H.; Mirarefein, M.; Ghaderpanahi, M.; Badamchizadeh, Z. and Larijani, B. 2010. Low serum leptin serves as a biomarker of malnutrition in elderly patients. Nutrition Resesarch 30:314-319.
Arosh, A. J.; Kathiresan, D.; Devanathan, T. G.; Rajasundaram, R. C. and Rajasekaran J. 1998. Blood biochemical profile in normal cyclical and anoestrous cows. Indian Journal of Animal Sciences 68:1154-1156.

Barash, I. A.; Cheung, C. C.; Weigle, D. S.; Ren, H.; Kabigting, E. B. and Kuijper, J. L. 1996. Leptin is a metabolic signal to the reproductive system. Endocrinology 137:3144-3147.

Block, S. S.; Butler, W. R.; Ehrhardt, R. A.; Bell, A. W.; Van Amburgh, M. E. and Boisclair Y. R. 2001. Decreased concentration of plasma leptin in periparturient dairy cows is caused by negative energy balance. Journal of Endocrinology 171:341-350.

Block, S. S.; Smith, J. M.; Ehrhardt, R. A.; Diaz, M. C.; Rhoads, R. P.; Van Amburgh, M. E. and Boisclair, Y. R. 2003. Nutritional and developmental regulation of plasma leptin in dairy cattle. Journal of Dairy Science 86:3206-3214.

Burle, P. M.; Mangle, N. S.; Kothekhar, M. D. and Kalorey, D. R. 1995. Blood biochemical profiles during various reproductive states of Sahiwal and Jersey x Sahiwal cattle. Livestock Advances 20:13-20.

Ceylan, A.; Serin, I.; Aksit, H.; Seyrek, K. and Gökbulut, C. 2007. Döl tutmayan ve anöstruslu süt ineklerinde vitamin A, E, betakaroten, kolesterol ve trigliserid düzeylerinin araştırılması. Kafkas Üniversitesi Veteriner Fakültesi Dergisi 13:43-147.

Chilliard, Y.; Bonnet, M.; Delavaud, C.; Faulconnier, Y.; Leroux, C.; Djiane, J. and Bocquie, F. 2001. Leptin in ruminants. Gene expression in adipose tissue and mammary gland, and regulation of plasma concentration. Domestic Animal Endocrinology 21:271-295.

Cioffi, J. A.; Van Blerkom, J.; Antczak, M.; Shafer, A.; Wittmer, S. and Snodgrass, H. R. 1997. The expression of leptin and its receptors in pre-ovulatory human follicles. Molecular Human Reproduction 3:467-472.

Considine, R. V.; Sinha, M.K.; Heiman, M. L.; Kriauciunas,A.; Stephens, T. W.; Nyce, M. R.; Ohannesian, J. P.; Marco, C. C.; McKee, L. J.; Bauer, T. L. and Caro, J. F. 1996. Serum immunoreactive-leptin concentrations in normal-weight and obese humans. New England Journal of Medicine 334:292-295.

Dutta, J. C.; Baruah, R. N.; Dutta, L. and Talukdar, S. C. 1988. Blood biochemical studies in anoestrous and normal cyclic cattle. Indian Veterinary Journal 65:239-241.

Dutta, J. C.; Barman, N. N. and Baruah, R. N. 1991. Blood biochemical profile and microbial spectrum in repeat breeder cows. Indian Veterinary Journal 68:435-438.

El-Azab, M. A.; El-Sadawy, B. A.; Shawki, G. and Borkat, T. M. 1993. Some biochemical changes in relation to postpartum ovarian activity in dairy cows. Indian Journal of Animal Sciences 63:1244-1247.

El-Khadrawy, H. H.; Ahmed, W. M. and Hanafi, M. 2011. Observations on repeat breeding in farm animals with emphasis on its control. Journal of Reproduction and Infertility 2:01-07.

Gandotra, K.; Chaudhary, R. K. and Sharma, R. D. 1993. Serum biochemical constituents in normal and repeat breeding cows and buffaloes. Indian Veterinary Journal 70:84-85.

Goumenou, A. G.; Matalliotakis, I. M.; Koumantakis, G. E. and Panidis, D. K. 2003. The role of leptin in fertility. European Journal of Obstetrics Gynecology and Reproductive Biology 106:118-124.

Guedon, L.; Saumande, J.; Dupron, F.; Couquent, C. and Desbals, B. 1999. Serum cholesterol and triglycerides inpostpartum beef cows and their relationship to the resumption of ovulation. Theriogenology 51:1405-1415.

Haluzik, M.; Fiedler, J.; Nedvídková, J. and Ceska, R. 1999. Serum leptin concentrations in patients with combined hyperlipidemia: relationship to serum lipids and lipoproteins. Physiological Research 48:363-368. 
Haile, A.; Tsegaye, Y. and Tesfaye, N. 2014. Assessment of major reproductive disorders of dairy cattle in urban and per urban area of Hosanna, Southern Ethiopia. Animal and Veterinary Sciences 2:135-141.

Henry, B. A.; Goding, J. W.; Alexander, W. S.; Tilbrook, A. J.; Canny, B. J.; Dunshea, F.; Rao, A.; Mansell, A. and Clarke I. J. 1999. Central administration of leptin to ovariectomized ewes inhibits food intake without affecting the secretion of hormones from the pituitary gland: evidence for a dissociation of effects on appetite and neuroendocrine function. Endocrinology 140:1175-1182.

Kadokawa, H.; Blache, D.; Yamada, Y. and Martin, G. B. 2000. Relationships between changes in plasma concentrations of leptin before and after parturition and the timing of first post-partum ovulation in high-producing Holstein dairy cows. Reproduction Fertility and Development 12:405-411.

Lyubestsky, V. I. 1997. Plasma protein fractions in cows with post parturient edometritis. Visnik-Agrarnoi-Nauli. 6:28-33.

Majeed, M. A.; Iqbal, J. and Chaudhry, M. N. 1990. Blood chemistry of clinical merits in Nili-Ravi buffaloes of two age groups and at two stages of lactation. Pakistan Veterinary Journal 10:55-59.

Mann, G. E.; Mann, S. J.; Blache, D. and Webb, R. 2005. Metabolic variables and plasma leptin concentrations in dairy cows exhibiting reproductive cycle abnormalities identified through milk progesterone monitoring during the post partum period. Animal Reproduction Science 88:191-202.

Mounzih, K.; Lu, R. and Chehab, F. F. 1997. Leptin treatment rescues the sterility of genetically obese ob/ob males. Endocrinology 138:1190-1193.

Nagatani, S.; Zeng, Y.; Keisler, D. H.; Foster, D. L. and Jaffe, C. A. 2000. Leptin regulates pulsatile luteinizing hormone and growth hormone secretion in the sheep. Endocrinology 141:3965-3975.

Opsomer, G.; Coryn, M.; Deluyker, H. and Kruif, A. 1998. Risk factors for postpartum ovarian dysfunction in high producing dairy cows in Belgium: a field study. Reproduction in Domestic Animals 33:193-204.

Park, M. S.; Yang, Y. X.; Shinde, P. L.; Choi, J. Y.; Jo, J. K.; Kim, J. S.; Lohakare, J. D.; Yang, B. K.; Lee, J. K.; Kwon, I. K. and Chae, B. J. 2010. Effects of dietary glucose inclusion on reproductive performance, milk compositions and blood profiles in lactating sows. Journal of Animal Physiology and Animal Nutrution 94:677-684.

Parkinson, T. J. 2001. Infertility. p.463-464. In: Arthur's veterinary reproduction and obstetrics. 8th ed. Noakes, D. E.; Parkinson, T. J. and England, G. C. W., eds. Saunders Company, USA.

Qureshi, M. S. 1998. Relationship of pre and post partum nutritional status with reproductive performance in Nili-Ravi buffaloes under the conventional farming system in NWFP, Pakistan. Ph.D. Thesis. University of Agriculture Faisalabad, Pakistan.

Ramakrishna, K. V. 1996. Microbial and biochemical profile in repeat breeder cows. Indian Journal of Animal Reproduction 17:30-32.

Royal, M. D.; Darwash, A. O.; Flint, A. P. F.; Webb, R.; Wooliams, J. A. and Lamming, G. E. 2000. Declining fertility in dairy cattle: Changes in traditional and endocrine parameters of fertility. Animal Science 70:487-501.

Salmanoglu, R.; Küplülü, S.; Bastan, A.; Salmanoglu, B. and Vural, R. 1997. Çeşitli fertilite problemli holştayn irkı ineklerde kan betakarotin, retinol, glikoz ve kolesterol düzeyleri. Ankara Universitesi Veteriner Fakültesi Dergisi 44:151-157.

Singh, M. and Pant, H. C. 1998. Blood biochemical profile of normal and repeat breeding cows in Himachal Pradesh. Indian Journal of Animal Reproduction 19:56-157.

Sivan, E. E.; Whittaker, P. G.; Sinha, D. D.; Homko, C. J.; Lin, M. M.; Reece, E. A. and Boden, G. G. 1998. Leptin treatment rescues the sterility of genetically obese ob/ob males. American Journal of Obstetrics and Gynecology 179:1128-1132.

Sivitz, W. I.; Walsh, S. A.; Morgan, D. A.; Thomas, M. J. and Haynes, W. G. 1997. Effects of leptin on insulin sensitivity in normal rats. Endocrinology 138:3395-3401.

Spicer, L. J. 2001. Leptin: A possible metabolic signal affecting reproduction. Domestic Animal Endocrinology 21:251-270.

Taleb, M. H.; Younis, S. J.; Zabout, B.; Najim, A. A.; Ahmed, A. I. and El-Bayary E. S. 2014. Relationship of serum leptin, BMI, waist circumference and cholesterol level among teenagers in the gaza strip. Pharmacology and Pharmacy 5:789-795.

Vohra, S. C.; Dindorkar, C. V. and Kaikini, A. S. 1995. Studies on blood serum levels of certain biochemical constituents in normal cycling and anestrous cross bred cows. Indian Journal of Animal Reproduction 16:85-87.

Yadav, A.; Iyoti, P.; Jain, S. K. and Bhattacharjee, J. 2011. Correlation of adiponectin and leptin with insulin resistance: a pilot study in healthy North Indian population. Indian Journal of Clinical Biochemistry 26:193-196.

Y1lmaz, A.; Kayardi, M.; Icagasioglu, S.; Candan, F.; Nur, N. and Gültekin, F. 2005. Relationship between serum leptin levels and body composition and markers of malnutrition in nondiabetic patients on peritoneal dialysis or hemodialysis. Journal of Chineese Medical Association 68:566-570.

Zabut, B.; Naji, H.; Holi, B. and Yousef, A. 2007. Leptin and soluble leptin receptor among obese adults in the gaza strip. The Islamic University Journal (Series of Natural Studies and Engineering) $15: 127-140$ 